\title{
Literasi Kesehatan pada Anak Usia Dini melalui Kegiatan Eating Clean
}

\author{
Dinar Nur Inten ${ }^{1}$, Andalusia Neneng Permatasari ${ }^{2} \bowtie$ \\ ${ }^{1}$ Pendidikan Guru Pendidikan Anak Usia Dini, Universitas Islam Bandung \\ ${ }^{2}$ Ilmu Komunikasi, Universitas Islam Bandung
}

\begin{abstract}
Abstrak
Kegiatan eating clean bekal sehat di RA Al-Muqoddasah dilaksanakan sebagai bentuk kepedulian lembaga pendidikan terhadap kesehatan generasi penerus bangsa. Dengan menggunakan metode analisis dekriptif, peneliti menggambarkan bagaimana tumbuhnya kesadaran anak akan makanan sehat dari kegiatan Eating clean dan memperkenalkan anak untuk merasakan berbagai masakan dan olahan makanan sehat yang penuh gizi. Kegiatan tersebut terdiri atas fruit day, vegetable day, bread and milk day, tubers day, dan biscuit day. Hasilnya dari 25 orang anak $90 \%$ anak menyukai bekal makanan sehat yang bervariasi dan diolah dengan sehat dan $99 \%$ respon orang tua pun merasakan dampak dari eating clean, yaitu ketika mereka merasa terbantu untuk menyiapkan menu harian anak dan pengenalkan makanan sehat untuk anak. Pengenalan makanan sehat yang penuh nutrisi dan gizi seimbang bagi anak sedini mungkin sangatlah penting.
\end{abstract}

Kata Kunci: literasi kesahatan; anak usia dini; kegiatan eating clean

\begin{abstract}
Eating Clean in RA Al-Muqoddasah as a form of concern for educational institutions on the health of children. By using descriptive analysis method, the researcher described how the growing awareness of children about healthy food from Eating Clean activities and introducing children to experience various dishes and processed healthy foods that are full of nutrition. The activity consisted of fruit day, vegetable day, bread and milk day, tubers day, and biscuit day. As a result, $90 \%$ of children love the provision of healthy food that is varied and processed with health. $99 \%$ of the responses of parents also feel the effects of eating clean, which is when they feel helped to prepare children's daily menus and introduce healthy food for children. For healthy eating, there is also a share table whose function is to invite children to share food with friends. Children can feel a variety of processed healthy foods while being able to share their health with their friends.
\end{abstract}

Keywords: health literacy; early age; eating clean

Copyright (c) 2019 Dinar Nur Inten, Andalusia Neneng Permatasari

$\triangle$ Corresponding author:

Address : Jl Tamansari No. 1 Bandung

ISSN 2356-1327 (Media Cetak)

Email : andalusianp@gmail.com

ISSN 2549-8959 (Media Online) 


\section{PENDAHULUAN}

Anak usia dini merupakan individu yang sedang mengalami proses perkembangan yang fundamental bagi kehidupannya kelak. Pada tahapan usia dini, anak akan mengalami perkembangan dan pertumbuhan fisik serta mental yang cukup banyak. Pada usia ini pula anak akan merespons serta mengolah berbagai hal yang diterimanya dengan cepat. Oleh karena itu berbagai hal yang diterima oleh anak pada usia dini akan menjadi fondasi dasar bagi kehidupannya kelak. Menurut Rizqie Aulina (Aulina, 2011), gizi seimbang harus diterapkan sejak anak usia dini karena kelompok ini termasuk kelompok usia penting dan kelompok kritis tumbuh kembang manusia yang akan menentukan masa depan kualitas hidup manusia.

Kesehatan merupakan salah satu faktor utama dan sangat penting dalam perkembangan anak. Ketika kondisi kesehatan anak kurang sehat, akan berdampak pada berbagai hal yang berkaitan dengan perkembangnya dan terhadap berbagai aktivitas yang akan dilakukannya. Hal utama untuk menjaga kondisi kesehatan anak adalah dengan memerhatikan gizi yang terkandung dalam makanan yang dikonsumsi. Status gizi yang baik merupakan salah satu faktor penentu keberhasilan anak dalam belajar. Nutrisi buruk di awal tahun-tahun pertama usia anak dapat mengakibatkan lemahnya fokus, memori, dan kemampuan anak (Awaluddin \& Dkk, 2017).

Makanan merupakan kebutuhan mendasar bagi setiap manusia di bumi ini. Makanan yang dikonsumsi oleh anak berperan besar terhadap kehidupan masa depannya. Kecukupan gizi yang masuk ke tubuh anak berpengaruh pada kesehatan dan kecerdasan anak. Pola makanan yang dikonsumsi oleh anak sejak dini akan mempengaruhi dan bahkan menjadi pola makanan yang dibawanya sampai kelak sang anak dewasa. Oleh sebab itu, pengetahuan dan kemampuan orang tua serta orang dewasa di sekitar anak untuk mengelola makanan sehat sangatlah utama.

Pada saat ini, maraknya makanan junkfood dan instan yang lebih digemari oleh anak. Hal ini semakin menjadikan anak sulit untuk diperkenalkan pada makanan sehat yang penuh gizi dan vitamin. Berdasarkan data Kementrian Perencanaan Pembangunan Nasional/ Badan Perencanaan Pembangunan Nasional (BAPPENAS) pada tahun 2018 mencatat ada 9 juta anak di Indonesia yang mengalami stunting (Detiknews, 2018). Menurut Kennedy Simanjuntak, 9 juta anak tersebut tersebar di pedesaan dan perkotaan. Angka ini sangat besar hampir sama jumlahnya dengan satu negara (Detiknews, 2018). Bila pada usia dini anak sudah mengalami gizi buruk, akan mengganggu perkembangan dan pertumbuhannya. Bahkan, kemungkinan besar sang anak dapat mengidap berbagai penyakit yang berbahaya bagi keselamatan jiwanya.

Kementrian

Kesehatan mengungkapkan tingginya angka kekurangan gizi pada anak-anak. Kementrian Kesehatan membaginya menjadi tiga kategori. Kategori pertama, indeks kekurangan gizi menurut berat badan per usia. Di Indonesia, kekurangan gizi menurut berat badan per usia mencapai $17 \%$ melebihi batas WHO 10\%. Kategori kedua, indeks tinggi badan per usia, angka kekurangan gizi masih tinggi, yaitu 27.5\%. Adapun batas WHO adalah 20\%. Pada kategori ketiga, yaitu indeks berat badan per tinggi badan pun masih di atas batas WHO, angka kekurangan gizi mencapai $11 \%$, sedangkan batas WHO adalah 5\% (CNN Indonesia, 2017). 
Tingginya tingkat gizi buruk anak di Indonesia bisa jadi disebabkan beberapa faktor. Seperti, tingkat ekonomi dan sulitnya mencari pekerjaan yang berdampak terhadap kemampuan oarang tua untuk menyediakan makanan sehat sangatlah sulit, sanitasi yang buruk menyebabkan kondisi rumah tidak bersih dan berpengaruh pula terhadap makanan yang akan diolah, pendidikan sebagian orang tua memiliki tingkat pendidikan yang rendah yang menyebabkan mereka tidak mengetahui pentingnya asupan makanan yang bergizi bagi pertumbuhan dan perkembangan anak, serta berpengaruhnya asupan gizi pada anak untuk masa depannya. Sayoga (Sayoga, 2015), mengatakan bahwa gangguan kesehatan pada masa anak-anak di Indonesia antara lain disebabkan akibat gizi yang kurang sempurna, serangan penyakitpenyakit menular, keadaan lingkungan hidup yang kurang sehat, dan parasit-parasit atau cacing-cacing di dalam alat pencernaan.

Oleh karena itu, orang tua ataupun orang dewasa di sekitar anak memiliki peranan penting untuk membantu mengenalkan anak akan makanan sehat penuh gizi, menghindarkan anak dari makanan kekinian yang marak saat ini serta menyadarkan anak akan pentingnya makanan sehat agar mereka bisa tetap dapat bermain, bergembira dan jauhnya agar mereka dapat meraih cita-cita yang diimpikannya dengan kondisi sehat jasmani dan rohani. (Aristiana \& Dkk, 2015) mengemukakan hasil penelitian yang menunjukkan kebiasaan mengkonsumsi makanan sehat yang dilakukan orang tua akan berdampak terhadap pola makan anak. Pada penelitiannya, (Aristiana \& Dkk, 2015) menunjukkan data, yaitu pola makan orang tua yang tidak baik atau sehat, 56\% anaknya mengalami pola makan yang tidak baik dan mengalami kesulitan makan (Aristiana \& Dkk, 2015). Diperlukan upaya untuk menyadarkan anak atau membuat anak dan orang tua melek akan pentingnya makanan sehat bagi kehidupan.

Literasi artinya kemampuan dalam mengolah informasi dan pengetahuan untuk kecakapan hidup (Aplikasi KBBI Edisi 5). Negara yang maju identik dengan penduduk yang memiliki tingkat literasi yang tinggi pula. Rini (Handayani, 2014), mengatakan bahwa literasi kontemporer bermakna sebagai kemampuan seseorang dalam menggunakan informasi tertulis ataupun cetak untuk mengembangkan pengetahuan sehingga mendatangkan manfaat bagi masyarakat. Jadi yang dimaksud dengan literasi kesehatan adalah upaya penyadaran anak dan pencegahan agar anak terhindar dari berbagai gangguan kesehatan dan penyakit yang mengakibatkan perlunya dilakukan pemeriksaan, pengobatan, dan perawatan. Literasi kesehatan pada penelitian ini yaitu menumbuhkan pola hidup sehat pada anak sejak dini melalui kegiatan eating clean yaitu bekal harian yang berupa makanan sehat penuh gizi.

Anak usia dini merupakan sosok individu yang sedang mengalami perkembangan dan pertumbuhan yang pesat. Setiap rangsangan yang diberikan pada anak usia dini akan mendapatkan respons yang cepat pula. Berbagai hal yang didapatkannya pada usia dini akan menjadi dasar dan pondasi utama bagi kehidupannya kelak. Menurut Rusilanti, dkk (Rusilanti \& Dkk, 2015), usia prasekolah adalah usia 3-5 tahun dan merupakan kurun yang disebut masa golden age. Di usia ini, anak banyak mengalami perubahan baik fisik maupun mental, dengan karakteristik: berkembangnya konsep diri, rasa ingin tahu, imajinasi, belajar menimbang rasa, munculnya kontrol internal, belajar dari lingkungannya, berkembangnya cara berpikir, berkembangnya kemampuan bahasa, dan munculnya perilaku. 
Anak usia prasekolah tumbuh lebih besar, persentase kenaikan tinggi dan berat badan menurun di tiap tahun berikutnya. Anak perempuan hanya lebih kecil dan lebih ringan daripada anak laki-laki, anak perempuan lebih banyak jaringan lemaknya sedangkan anak laki-laki memiliki lebih banyak jaringan otot (Santrock, 2007). Semua hal itu dipengaruhi oleh hereditas dan asupan gizi yang di konsumsi oleh anak.

Anak tumbuh dan berkembang sesuai asupan gizi yang diterimanya. Anak selalu tumbuh dan berkembang sejak konsepsi sampai akhirnya masa remaja. Hal ini yang membedakan anak dengan orang dewasa. Anak bukan miniatur orang dewasa dan bukan pula orang dewasa. Anak menunjukkan ciri-ciri pertumbuhan dan perkembangan yang sesuai usianya. Pada umumnya pertumbuhan dan perkembangan anak mempunyai ciri-ciri yang saling berkaitan dan pertumbuhan dan perkembangan anak merupakan hasil interaksi banyak faktor yang mempengaruhi kedua hal tersebut (Rivanica \& Oxyandi, 2016)

Berbagai hal yang disampaikan pada usia dini memiliki peranan penting yang akan menjadi pondasi seorang individu di masa dewasanya. Uyu \& Mubiar (Uyu \& Mubiar, 2011) mengatakan bahwa 50\% perkembangan anak dialami ketika anak usia 0-4 tahun, di usia 8 tahun $80 \%$ kapasitas kecerdasan anak telah terjadi. Maka dari pada itu berbagai hal yang berkaitan dengan pengetahuan dan keterampilan dasar kehidupan salahsatunya pengenalan makanan sehat dan bergizi sebaiknya dikenalkan ketika anak berusia dini sehingga ketika dia menginjak dewasa anak sudah terbiasa dengan pola hidup sehat dan makanan sehat.

Perkembangan dan pertumbuhan anak pada usia dini sangatlah penting, maka wajar kalau orang tua, para pendidik anak usia dini dianjurkan untuk mengetahui dan memahami perkembangan anak. Yusuf mengatakan alasan pentingnya memahami perkembangan anak karena pertama, masa anak merupakan periode perkembangan yang cepat dan terjadinya perubahan dalam banyak aspek perkembangan.(Yusuf, 2009)

Kedua, pengalaman masa kecil mempunyai pengaruh yang kuat terhadap perkembangan selanjutnya. Ketiga pengetahuan tentang perkembangan akan dapat membantu anak mengembangkan diri, memecahkan masalah yang dihadapinya. Keempat, melalui pemahaman yang baik mengenai perkembangan anak maka dapat diantisipasi tentang berbagai upaya untuk memfasilitasi anak dari sisi keluarga, sekolah dan masyarakat. Setelah memahami dan mengetahui perkembang anak maka hal yang tak kalah penting untuk mengoptimalkan perkembangan anak adalah makanan yang sehat dan bergizi.

Gizi adalah suatu proses organisme menggunakan makanan yang dikonsumsi secara normal melalui proses pencernaan, absorpsi, transportasi, penyimpanan, metabolisme, dan pengeluaran zat-zat yang tidak digunakan untuk mempertahankan kehidupan, pertumbuhan, dan fungsi normal dari organ-organ serta menghasilkan energi (Rusilanti \& Dkk, 2015). Jadi, makanan bergizi adalah makanan yang cukup berisi bermacam-macam jenis sari makanan (Sayoga, 2015). Makanan yang sehat adalah makanan yang seimbang yang mengandung biji-bijian, sayuran, daging, dan sedikit lemak dan gula, karena lemak dan gula berada pada piramid makanna tingkat atas yang artinya porsi maknnya sedikit saja (Rita, 2011).

Agama pun memerintahkan kita untuk membiasakan anak hidup sehat dan mengkonsumsi makanan serta minuman sehat sejak mereka usia dini. Diriwayatkan 
oleh Imam Ahmad dan Tirmidzi bahwa Rasululloh bersabda “ tidaklah seorang anak Adam memenuhi tempat paling jelek kecuali perutnya, cukuplah bagi anak Adam beberapa suap makanan yang bisa menegakkan tulang rusuknya. Namun bila ia terpaksa melakukannya, maka hendaklah sepertiga (isi lambungnya) untuk makanan, sepertiga untuk minuman, dan sepertiga isinya untuk udara (Ulwan, 2017). Masih dari Nashih Ulwan, biasakan anak untuk gemar berolahraga karena olahraga membuat mereka sehat dan kuat. (Ulwan, 2017)

Rasulalloh bersabda yang diriwayatkan oleh Imam Muslim "Mukmin yang kuat itu lebih baik dan lebih dicintai Alloh daripada mukmin yang lemah". Oleh karena itu, Islam mengajak orang tua untuk mengenalkan pada anak-anak olahraga renang, melempar, menunggang kuda.

Hidup sehat berarti hidup yang seimbang, baik antara olah raga dan makanan yang kita konsumsi, ataupun dalam makanan yang kita konsumsi harus mengandung kesimbangan gizi yang dikenal dengan empat sehat lima sempurna yang terdiri dari nasi, lauk pauk, buah, sayur dan susu. Empat sehat lima sempurna artinya makanan sehari-hari yang terdiri atas nasi, jagung, sagu dan kentang atau roti yang berguna sebagai sumber tenaga. lauk pauk, ikan, daging, telor, tahu, tempe, kedelai, yang berguna sebagai zat putih telur. sayur mayor sebagai sumber mineral dan vitamin. Buah-buahan sebagai sumber vitamin dan mineral. Susu sapi atau susu hewan lainnya sebagai makanan tambahan yang mengandung zat putih telur, zat lemak, zat gula, vitamin, dan zat mineral (Sayoga, 2015)

Kekurangan

mengakibatkan pertumbuhan, kurangnya tenaga, penurunan daya tahan tubuh dan timbulnya penyakit-penyakit tertentu. Beberapa penyakit yang timbul dikarenakan kekurangan gizi adalah busung lapar, kwashiorkor (kekurangan zat putih telur), kebutaan akaibat kekurangan vitamin A, kekurangan vitamin D yang menyerang bagian-bagian tulang, kekurangan vitamin C penyakit kulit gusi berdarah sariawan, lesu darah atau anemia, dan gondok atau keratin (Sayoga, 2015).

Beberapa hal yang perlu diperhatikan agar anak usia dini mendapatkan gizi seimbang untuk tumbuh kembangnya. Pertama, makanan selalui bervariasi meliputi makanan pokok, lauk pauk, sayuran dan buah. Kedua, variasikan cara mengolah bahan makanan sehingga semua bahan makanan dapat masuk dalam makanan anak. Ketiga, berikan air putih setiap habis makan. Keempat, hindari memberikan makanan selingan mendekati jam makan utama. Kelima, ketika usia 2 tahun jelaskan manfaat makanan yang harus dimakan sehingga dapat mengurangi rasa tidak sukanya (Aulina, 2011)

Kegiatan eating clean merupakan kegiatan turunan dari sebuah program yang bernama clean to be clean makan pintar makan sehat di yayasan pendidikan Islam Al-Muqoddasah. Program ini terlahir dikarenakan kepedulian dan kekhawatiran yayasan Al-Muqoddasah akan maraknya makanan junk food dan instant, dan tingkat obesitas anak saat ini. Kegiatan eating clean merupakan pembiasaan pola makan sehat untuk menjaga kesehatan tubuh. Pembiasaan makan sehat ini membatasi anak dari makanan tidak sehat dan mengurangi makanan siap saji (Darmasyeti, 2016). Tujuan dari kegiatan ini yaitu membiasakan makan sehat sejak dini, melatih anak makan berbagai jenis makanan bergizi, memenuhi asupan gizi seimbang yang diperlukan tubuh anak, anak terbiasa memakan buah dan sayur, serta mempermudah orang tua dalam menyiapkan menu makan bekal untuk anak. 
Kegiatan ini dilakukan serentak pada semua tingkat pendidikan anak usia dini pada yayasan pendidikan Al-Muqoddasah. Pelaksanaannya setiap hari dengan menu sehat, yaitu hari Senin fruit day (buahbuahan dan air mineral), hari Selasa vegetable day (sayuran dan air mineral), hari Rabu bread and milk day (roti, susu, dan air mineral), hari Kamis tubers day (umbi-umbian dan air mineral), serta hari Jumat biscuit day (biskuit dan air mineral) (Darmasyeti, 2016).

\section{METODOLOGI}

Metode yang digunakan peneliti dalam penelitian ini adalah deskriptif analitis, yaitu menggambarkan keadaan di lapangan berupa kegiatan eating clean, menyandingkan antara teori dari ahli dengan hasil observasi, wawancara dan hasil penyebaran angket kegiatan eating clean pada 20 orang guru dan orang tua. Selanjutnya, pada akhirnya melaporkan hasil obeservasi dan angket dalam bentuk narasi yang disandingkan dengan teori dari para ahli.

\section{HASIL DAN PEMBAHASAN}

Hidup sehat dengan mengkonsumsi makanan yang kaya gizi dan nutrisi harus dimulai sejak dini. Hal ini bisa dilakukan melalui kegiatan eating clean pada tingkat kelompok bermain dan kelompok A serta kelompok B di yayasan pendidikan Islam Al-Muqoddasah Jagabaya, Kecamatan Cimaung, Kabupaten Bandung.

Menurut Santrock (Santrock, 2007) apa yang dimakan oleh anak mempengaruhi pertumbuhan kerangka tubuh dan kerentanan mereka terhadap penyakit. Anak-anak prasekolah mulai mengenal makanan cepat saji atau instan dikarenakan mereka mulai keluar rumah dan melihat lingkungan sekitarnya. Rata-rata makanan cepat saji banyak mengandung lemak yang tidak baik bagi kesehatan, bahkan apabila mengkonsumsi berlebih akan memicu berbagai penyakit. Sedangkan anak-anak prasekolah membutuhkan keseimbangan asupan gizi yang baik untuk mendukung pertumbuhan dan perkembangan hidupnya.

Gambaran awal bekal harian anakanak Al-Muqoddasah sebelum diberlakukan kegiatan eating clean, $70 \%$ anak selalu membawa makanan cepat saji, seperti mie goreng, sosis, dan makanan ringan, seperti kerupuk ataupun chiki. Minuman didominasi oleh susu kemasan. 20\% lainnya membawa makanan, seperti nasi goreng, nasi dengan lauk ayam dan telur, roti, dan minum air putih. Adapun $10 \%$ anak jarang membawa bekal dengan alasan sudah makan di rumah jadi cukup beli jajanan ketika istirahat di sekolah. Dari semua bekal tersebut, jarang sekali atau bahkan tidak terlihat anak membawa bekal sayuran ataupun buah yang menjadi sumber gizi yang baik untuk pertumbuhan dan perkembangannya.

Bekal harian yang dibawa anak pun kadang sering tidak habis karena menurut anak-anak bekalnya tidak mereka sukai. Mereka juga bosan karena bekalnya selalu sama tidak bervariasi dan terlalu banyak sehingga membuat mereka enggan untuk makan dan menghabiskannya. Akhirnya, asupan gizi yang diperlukan anak sebagai pengganti energi yang telah dikeluarkannya dari pagi hingga siang tidak terganti dengan optimal. Hal inilah yang menjadi salah satu penyebab anak akhirnya berlari ke warung untuk jajan. Menurut Titik dan Agus, (Titik \& Agus, 2014), salah satu kelompok masyarakat yang sering mengalami keracunan makanan jajanan adalah anak sekolah, karena jajanan sekolah berisiko terhadap cemaran biologis atau kimiawi yang banyak mengganggu kesehatan, baik jangka pendek maupun jangka panjang. 
Pola makan orang tua di rumah akan diikuti oleh anak dalam kesehariannya. Oleh karena itu, orang tua, terutama ibu sebaiknya memiliki pengetahuan tentang gizi seimbang anak agar dapat menghidangkan makanan yang penuh gizi dan sehat untuk anak. Pengetahuan ibu akan gizi bisa diperoleh melalui membaca, pelatihan, ataupun penyuluhan yang diselenggarakan di sekolah ataupun posyandu. Berdasarkan penelitian yang dilakukan oleh Syafriani (Syafriani, 2016), penyuluhan pengetahuan tentang gizi seimbang efektif disampaikan pada ibu-ibu melalui kegiatan posyandu. Salah satu tujuan diselenggarakan eating clean di RA Al-Muqoddasah adalah memperkenalkan pola makanan sehat pada anak, apabila di rumah orang tua tidak punya cukup pengetahuan untuk memperkenalkan pola makan yang sehat dan bergizi.

Orang tua merupakan contoh dan teladan bagi anak. Setiap perkataan dan perbuatan yang dilakukan oleh orang tua akan ditiru oleh anak, oleh karena itu pola makan sehat dan tidak yang dilakukan oleh orang tua di rumah akan berpengaruh terhadap pola makan anak. Sering pula orang tua dikarenakan kesibukannya hanya dapat memberikan bekal ke sekolah seadanya tidak memperhatikan gizi yang harus dipenuhi bagi pertumbuhan anak. Berdasarkan penelitian yang dilakukan oleh Dewi dan Ratna (Dewi \& Ratna, 2014), sebagian orang tua tidak mau repot untuk membuat bekal anaknya sehingga bekal yang dibawa anak tidak mengandung gizi seimbang, porsinya terlalu banyak bahkan beberapa anak membawa bekal yang mengandung zat pewarna.

Pada awalnya, pelaksaan Eating Clean sebagai kegiatan pengenalan bekal sehat pada anak belum berjalan dengan optimal. Masih ada beberapa anak yang lupa membawa bekal sehat dan beberapa anak masih enggan untuk memakan bekal sehatnya karena masih asing dan masih beradaptasi akan makanan tersebut. Namun, seiring waktu setelah enam bulan berlalu kegiatan Eating Clean dapat berjalan dengan, baik bahkan hasilnya pun optimal. Berikut ini kegiatan Eating Clean yang dilaksanakan di RA Al-Muqoddasah dan dampaknya terhadap pola makan anak.

Ketika kegiatan mulai disosialiasikan, orang tua mulai berlomba untuk menyajikan bekal makanan sehat yang menarik untuk anak sesuai dengan menu yang diberikan oleh pihak sekolah. Untuk menu buah-buahan yang dilakasanakan pada hari Senin, anak-anak dibekali berbagai jenis buah, ada yang buah segar, ada pula yang di jus ataupun divariasikan dengan mayonaes. Jenis buah-buahan yang dibawa anak adalah $70 \%$ buah jeruk, apel, semangka. $30 \%$ anak membawa buah pepaya, pisang, naga, duku, manggis, lengkeng, leci, dan rambutan. Dalam setiap minggu, anak harus selalu bekal buah, yaitu pada hari Senin. Akhirnya, karena tiap minggu terbiasa satu hari makan buahbuahan, tumbuhlah sedikit demi sedikit kesukaan anak akan buah. Dari 25 orang anak, hanya 2 orang anak saja yang masih kurang menyukai buah-buahan atau hanya $8 \%$ yang kurang suka buah.

Setiap hari Selasa bekal sehat yang harus dibawa anak-anak adalah sayuran dan air mineral. Beraneka masakan dibuat oleh para ibu dari sayuran. $80 \%$ adalah sayuran yang dikombinasi seperti sayur sop dengan sosis, sayur bayam dengan sedikit bakso yang dicincang, sayur capcay dengan suiran ayam, dan sayur kangkong dengan telur puyuh. Sedangkan $20 \%$ lainnya bekal sayur yang ditambah dengan perkedel, nugget, ataupun telur dadar. Hal ini dikarenakan anak belum sepenuhnya menyukai sayur. Jadi, dengan porsi sedikit sayur dan sedikit lauk tambahan dapat memicu semangat anak untuk makan sayuran. Sebagian anak, ada pula yang membawa bekal tambahan 
berupa nasi putih, yaitu sebanyak $20 \%$ anak.

Hari Rabu bekal sehat anak adalah roti, susu, juga air mineral. Pada tiap hari Rabu, aneka ragam roti dibawa anak. $100 \%$ anak membawa roti dan susu. Roti yang dibawa ada roti manis, roti asin, dan juga donat mini. Dari $100 \%$ yang membawa roti $80 \%$ membawa roti berasa manis, sedangkan $20 \%$ lainnya rasa asin. Sedangkan untuk susu anak-anak sebagian besar membawa susu kemasan dalam kotak. Hanya $10 \%$ anak membawa susu yang disimpan di tempat minum atau diseduh. Untuk rasa susu, $80 \%$ anak menyukai rasa coklat dan strawberry. Hanya 20\% yang membawa susu dengan rasa vanilla ataupun susu tawar. $90 \%$ anak menghabiskan roti dan susu yang dibawanya. $10 \%$ tidak menghabiskan karena roti yang keras ataupun rasa susu yang tidak disukai dan terlalu banyak yang terkadang membuat anak mual dan muntah.

Pada kegiatan eating clean bekal sehat guru menyiapkan share table, yang berfungsi untuk menyimpan sekaligus menyajikan bagian kecil dari bekal yang dibawa anak sehingga setiap anak dapat berbagi dengan temannya sekaligus dapat mencicipi dan merasakan berbagai makanan sehat lainnya.

Pada hari Kamis, bekal umbi-umbian dan air mineral dibawa anak. Olahan dari umbi-umbian sangat beragam. Mulai dari umbi hanya dikukus, umbi yang digoreng, dan ada juga yang diolah menjadi berbagai kudapan tradisional yang berasa manis, seperti kelepon, getuk, ongol-onggol, putri noong, dan misro. Tapi, tidak sedikit pula yang membawa bekal kentang goreng, singkong goreng tabur keju, dan ubi arnet rebus. Anak yang membawa kentang dengan olahannya sebanyak 70\%. 20\% di antaranya membawa singkong atau olehannya dan $10 \%$ membawa ubi. Setelah kegiatan Eating Clean menu Kamis ini berjalan rutin, sebanyak $60 \%$ anak menyukai makanan dari umbi-umbian, $20 \%$ anak suka umbi tapi harus diolah, sedangkan $20 \%$ sisanya masih dalam tahap pengenalan makanan dari jenis umbiumbian. Mereka bekal tapi masih dengan takaran sedikit, misalnya kentang dibuat perkedel dan ditambah dengan sedikit nasi putih.

Hari Jumat, anak-anak membawa bekal biskuit dan susu. Biskuit yang dibawa anak rata-rata adalah biskuit yang dikemas dan sudah ada di pasaran, rasanya macammacam namun tetap $80 \%$ yang banyak dibawa anak adalah biskuit rasa coklat dan strawberry. Begitu pula dengan susu anak lebih memilih membawa susu kotak atau yang sudah dikemas. Hanya 1 anak dari 20 anak yang membawa susu soya dengan alasan kesehatan.

Kegiatan Eating Clean berdampak sangat baik terhadap pengetahuan anak akan makanan sehat serta pola makanan yang dikonsumsi anak. Melalui Eating Clean, $90 \%$ anak mengetahui manfaat dari buah-buahan, sayuran, umbi-umbian, biskuit, roti, susu, dan air putih bagi tubuh. Anak-anak mengatakan bahwa sayuran sangat baik bagi tubuh, seperti wortel yang membuat mata kita tetap sehat sampai tua dan sayuran yang bermanfaat agar kita mudah buang air besar.

Anak-anak juga menjadi paham bahwa buah-buahan baik bagi tubuh kita karena mengandung banyak vitamin $\mathrm{c}$ dan menyehatkan. Sedangkan umbi-umbian dapat kita konsumsi sebagai pengganti nasi. Hanya $10 \%$ anak yang belum mengetahui secara jelas manfaat bekal sehat. Eating Clean mengenalkan pada anak akan berbagai makanan yang belum pernah mereka makan sebelumnya terutama makanan ubi-ubian yang di rebus, sayuran 
rebus, susu murni ataupun nasi merah yang sangat jarang disajikan di rumah.

Pola makan anak berubah dengan cukup cepat melalui kegiatan Eating Clean. Anak menjadi terbiasa untuk tidak jajan di sekolah. Hal ini dikarenakan anak-anak sudah mengetahui manfaat makanan dan tahu makanan apa saja yang sehat bagi tubuhnya. Begitu pula di rumah, anak banyak menyampaikan makanan apa saja yang sebaiknya ibu mereka masak agar tubuh tetap sehat. 95\% anak sedikit demi sedikit menyukai makanan yang direbus, terutama seperti labu, wortel, dan juga buah-buahan segar, serta air putih. Menurut penelitian Erni \& Mariyam (Purwani \& Mariyam, 2013) ada hubungan antara peberian makanan sehat dengan status gizi anak usia 1- 5 tahun. Dan pemberian maknaan sehat dipengaruhi oleh tingkat pengetahuan ibu yang tinggi tentang pentingnya gizi bagi anak.

Air putih menjadi minuman yang wajib dibawa tiap hari. hal ini agar anak terbiasa meminum air putih kapan pun dan dimana pun mereka berada. Air putih sangat baik untuk kesahatan, dan dapat meminimalisasikan keinginan anak untuk meminum minuman kemasan yang manis dan dapat memicu berbagai penyakit.

Orang tua mengapresiasi kegiatan ini. Saat diwawancarai, orang tua menyatakan bagus dan setuju, serta mendukung kegiatan Eating Clean bekal sehat dilaksanakan di sekolah dengan alasan anak tidak jajan, tidak perlu pusing memikirkan menu bekal anak, anak jadi mengenal berbagai jenis makanan, anak mengenal makanan sehat, membuat anak suka sayuran dan buah, anak memiliki kesadaran sendiri dengan memilih makanan seperti buah, sayur, dan hidangan yang direbus, serta keinginan anak untuk mengkonsumsi makanan instan berkurang. Melalui kesadaran anak akan konsumsi makanan sehat, orang tua sekaligus dapat membangun kemandirian anak akan kemampuannya memilih makanan dan jajanan sehat, baik dan tidak membahayakan dirinya. menurut Ervin (Affrida, 2017), kemandirian anak usia prasekolah dibentuk melalui pola asuh membiasakan anak aktivitas sederhana untuk memenuhi kebutuhan diri sehari-hari untuk memenuhi kebutuhan diri sendiri. Kegiatan Eating Clean menumbuhkan kesadaran pada anak akan makanan sehat sejak dini. Kegiatan Eating Clean akan mengantarkan anak-anak menjadi generasi Indonesia yang sehat, cerdas, dan tangguh.

\section{KESIMPULAN}

Kegiatan eating clean di RA AlMuqoddasah yang berupa bekal sehat tiap hari berdampak signifikan terhadap perubahan pola makan anak baik di sekolah maupun di rumah. Anak-anak jadi terbiasa untuk makan buah, sayuran, umbi-umbian dan minum susu. Anak-anakpun jadi mengenal berbagai makanan sehat, dan manfaatnya bagi tubuh mereka, mereka pun sudah dapat memilih jajanan yang sehat untuk dirinya.

Dengan adanya share table yang disiapkan guru dalam kegiatan eating clean anakpun dapat berbagi dan merasakan makanan yang dibawa teman-temannya sehingga mereka memiliki pengetahuan tentang berbagai macam dan rasa makanan sehat. Untuk orang tua kegiatan eating clean membantu mereka dalam mengenalkan makanan sehat serta menyusun bekal menu sehat penuh gizi seimbang. Eating clean membantu mewujudkan generasi mendatang yang sehat dan kuat..

\section{UCAPAN TERIMA KASIH}

Peneliti mengucapkan terima kasih kepada ketua Yayasan dan para guru RA Al-Muqoddasah yang telah mengijinkan dan membantu peneliti untuk melakukan 
penelitian di lembaganya. Dengan diterbitkannya artikel ini, peneliti mengucapkan terima kasih kepada dewan redaksi jurnal Obsesi yang memberi kesempatan kepada peneliti untuk berbagi ilmu, sehingga hasil penelitian ini menjadi berkah untuk kemajuan ilmu pendidikan anak usia dini.

\section{DAFTAR PUSTAKA}

Affrida, E. N. (2017). Strategi Ibu dengan Peran Ganda dalam Membentuk Kemandirian Anak Usia Prasekolah. Jurnal Obsesi: Jurnal Pendidikan Anak Usia Dini, 1(2), 114-130. https://doi.org/10.31004/obsesi.v1i2.2 4

Aristiana, \& Dkk. (2015). Faktor-Faktor yang Berhubungan dengan Perilaku Kesulitan Makan Anak Prasekolah. Jurnal JOM, 2(2). Retrieved from https://media.neliti.com/media/public ations/186053

Aulina, R. (2011). Gizi Seimbang dan Makanan Sehat Untuk Anak Usia. Parenting Class Di Islamic Baby School Playgroup and Child Care "Rumah Ibu," 4.

Awaluddin, \& Dkk. (2017). Hubungan Status Gizi dengan Hasil Belajar Siswa Kelas 1 SD Negeri 5 Banda Aceh. Jurnal Pesona Dasar, 5(2). Retrieved from www.jurnal.unsyiah.ac.id

CNN Indonesia. (2017, March 9). Angka keurangan Gizi Indonesia di atas Ambang Batas WHO.

Darmasyeti. (2016). Panduan Program Eating Clean Balai Pendidikan AlMuqoddasah (pp. 1-2). pp. 1-2. Bandung.

Detiknews. (2018, March 28). Juta Anak Indonesia Kekurangan Gizi. Retrieved from https://m.detik.com.

Dewi, \& Ratna. (2014). Upaya meningkatkan Pengatahuan Makanan Sehat Melalui Penerapan Sentra Cooking Pada Kelompok B di PAUD Baitus Syibyan Kecamatan Bergas Kabupaten Semarang. Jurnal Penelitian PAUDIA, 3(1), 163. https://doi.org/10.26877/paudia.v3i2 $\% 20$ Oktober.510

Handayani, R. (2014). Literasi untuk Edukasi Bencana oleh Ririn Handayani - Kompasiana.com. Retrieved July 4, 2019, from Kompasiana website: https://www.kompasiana.com/ririnha ndayani/54f4b0f97455137c2b6c8cdb/ literasi-untuk-edukasi-bencana

Purwani, E., \& Mariyam. (2013). Pola Pemberian Makanan dengan Status Gizi Anak Usia 1 Sampai 5 Tahun di Kabunan Taman Pemalang. Jurnal Keperawatan Anak, 1(1), 903-1915. Retrieved from https://jurnal.unimus.ac.id/index.php/ JKA/article/view/903

Rita. (2011). Pendidikan Gizi Untuk Anak Usia Dini. Jurnal Educhild, 4(2), 110. Rivanica, \& Oxyandi. (2016). Buku Ajar Deteksi Dini Tumbuh Kembang Dan Pemeriksaan Bayi Baru Lahir. Jakarta: Salemba.

Rusilanti, \& Dkk. (2015). Gizi dan Kesehatan Anak Prasekolah.

Bandung: Rosdakarya.

Santrock, J. W. (2007). Perkembangan Anak (Vol. 1). Jakarta: Erlangga.

Sayoga. (2015). Pendidikan Kesehatan untuk Sekolah Dasar. Bandung: Rosdakarya.

Syafriani. (2016). Efektifitas Penyuluhan Terhadap Pengetahuan Ibu Balita Tentang Menu Seimbang Balita Di Posyandu Melati Desa Muara Langsat Kuantan Singingi. Jurnal Obsesi: Jurnal Pendidikan Anak Usia Dini, 2(2). 
376 | Literasi Kesehatan pada Anak Usia Dini melalui Kegiatan Eating Clean https://doi.org/10.31004/obsesi.v2i2.3 6

Titik, \& Agus. (2014). Pentingnya Memilih Jajanan Sehat Demi Kesehatan Anak. Jurnal Inovasi Dan Kewirausahaan, 3(3), 192-196. Retrieved from http://jurnal.uii.ac.id/ajie/article/down load/7832/6844

Ulwan, N. (2017). Pendidikan Anak dalam Islam. Solo: Insan Kamil.

Uyu, \& Mubiar. (2011). Penilaian Perkembangan Anak Usia Dini. Bandung: Refika Aditama.

Yusuf, S. (2009). Psikologi Perkembangan Anak dan Remaja. Bandung: Rosdakarya. 